식물유래 생리활성물질의 병원성 미생물 및 반추위 미생물

활성에 대한 영향

옥지운* . 이상민* . 임정화* . 이신자* · 문여황** . 이성실*

경상대학교 응용생명과학부*, 진주산업대학교 동물생명과학과**

\title{
Effects of Plant-origin Biological Active Materials on the Activities of Pathogenic Microbes and Rumen Microbes
}

J. U. Ok*, S. M. Lee*, J. H. Lim*, S. J. Lee*, Y. H. Moon** and Sung S. Lee*

Division of Applied Life Science, GyeongSang National University*,

Department of Animal Sci. \& Biotech., RAIRC, Jinju National University**

\begin{abstract}
In order to know the effects of Garlic, Scallion, Flavonoid, Urushiol, Anthocyanidin and Bio-MOS ${ }^{\circledR}$ on pathogenic microbes and rumen anaerobic microbes, the growth rate of pathogens (including Escherichia coli O157, Salmonella paratyphi, Listeria monocytogenes and Staphylococcus aureus) and in vitro rumen microbial growth, gas production, ammonia concentration, carboxymethylcellulase(CMCase) activity, and microbial populations were investigated.

The growth of pathogens was inhibited by supplementation of $0.1 \%$ Flavonoid, Scallion or Bio-MOS ${ }^{\circledR}$ as biological active materials. And Scallion and Flavonoid had powerful antimicrobial properties on the pathogens applied in paper disc method.

Although few effects by biological active materials disappeared in rumen fermentation in vitro, CMCase activity removed with supplementation of $1 \%$ of Flavonoid which had antimicrobial property in paper disc method. Scallion, having powerful antimicrobial property on pathogens and no inhibiting on rumen fermentation, might be a source in development of natural antimicrobial agent for ruminants.
\end{abstract}

(Key words : Biological active materials, Pathogenics, Rumen microbes)

$$
\text { I. 서 론 }
$$

천연 항생 세균이나 식품의 품질에 대한 기 준이 안전성에 절대적인 비중을 두게 됨으로써 환경 친화적인 천연자원으로부터 소재개발에 많은 관심을 가지게 되어 수 천년동안 인류가 섭취해 오면서 생리나 대사에 영향을 끼치지 않았던 소재로부터 필요한 천연 항균물질을 추 출하여 안전한 천연 항균물질을 개발하는 것이
중요하다. 식물로부터 추출된 생리활성물질로 서 적포도에서 추출한 anthocyanidian은 항산화 물질로 항암작용이 있으며, 옻나무에서 추출한 flavonoids와 urushiol(Miller, 1996)은 항암작용, 항산화작용 및 AIDS 환자에게 면역증강작용이 있다고 알려져 있다. 부추는 클로로필, $\beta$-카로 틴, 비타민 C, 함황화합물, 플라보노이드류 등 이 함유되어 있는데(박 등, 2002), 특히 함황화 합물(thiosulfinate 계열)은 O157을 비롯한 대장

Corresponding author: Sung S. Lee, Division of Animal Science and Technology, Gyeongsang National University, Jinju 660-701, Gyeongnam, Korea. Tel : 055-751-5410, E-mail : lss@gsnu.ac.kr 
균과 그람 양성균에도 강력한 항균력을 가지고 있고(Hong 등, 2000; Seo 등, 2001), 항산화 효 과 및 유해산소 소거작용까지 하는 것으로 밝 혀져 있다(Mortensen 등, 1997). 마늘에는 항균, 항암, 류머티즘, 항염증 등의 효과가 있음이 알 려져 있는데(Ali 등, 2000), 마늘의 주요 성분인 allicin은 여러 가지 생리작용을 나타내며, 식품 의 맛과 보존능력을 증진시킬 뿐만 아니라, 식 중독균과 같은 병원성균의 증식을 억제하는 항 균력을 가지고 있다(Sheo, 1999; Kumar와 Bernal, 1998; Akiko 등, 1993).

본 연구는 생리적 활성이 있다고 알려져 있 는 식용가능한 천연물이나 그로부터 추출된 생 리활성물질을 이용하여 병원성 미생물에 대한 항균활성을 확인하고, 아울러 반추위 미생물 배 양 시 가스 발생량, 암모니아 농도, 섬유소 분 해효소 활력 및 미생물 수를 측정함으로써 혐 기성균에 대한 저해효과 여부도 확인해 보고자 수행되었다.

\section{ㅍ. 재료 및 방법}

\section{1. 공시 생리활성물질 및 항생제}

본 시험에 사용된 생리활성물질은 식품으로 이용하고 있거나, 식용 가능한 것으로 이미 알 려져 있는 5 종의 식물로부터 즙액이나 성분을 추출하여 공시하였으며, 기존의 항균성 사료첨 가제로서 Alltech 사에서 제조한 Bio-MOS ${ }^{\circledR}$ 가 비교물질로서 공시되었다.

마늘과 부추는 국내산을 시중에서 구매하여 잘 씻은 다음, 물기를 말리고 녹즙기로 즙액을
내었다. 식물에게 저온 stress를 부여하여 미지 의 생리활성물질을 다량으로 분비시키기 위하 여 냉동실 $\left(-4^{\circ} \mathrm{C}\right)$ 에서 3 일간 방치하였다. 방치한 다음 맑게 떠오른 상층액을 filter paper로 거른 다음 조추출액을 시료로 사용하였다.

옻나무에서 추출한 flavonoid와 urushiol은 (주) 생명의나무 부설 천연물 과학 연구소로부터 증 여 받아 시험의 공시 시료로 사용하였다.

Anthocyanidin은 포도 씨앗과 껍질을 열수처 리하여 가온한 다음에 에탄올로 추출하여 동결 건조한 제품으로서 시중에서 구매(중국산)하여 사용하였다.

생리활성물질의 농도 $(0.001,0.01,0.01,1.00,5.00$ 및 $10.00 \%)$ 는 용매로 사용한 methylene chloride $\left(\mathrm{CH}_{2} \mathrm{Cl}_{2}\right)$ 의 양으로 조절하여 사용하였다. Positive (+) 대조구로서 사용된 항생제는 Sigma(SigmaAldrich Co, St. Louis, Mo, USA)로부터 streptomycin sulfate(S9137), penicillin G potassium(P7794) 및 chloramphenicol(C1919)를 구입하여, 역가를 고 려하여 각각 $0.606 \mathrm{~g}, 0.132 \mathrm{~g}$ 및 $0.030 \mathrm{~g}$ 을 300 $\mathrm{ml}$ 의 멸균증류수에 용해하여 사용하였다. Table 1 은 공시된 생리활성물질에 대한 정보를 나타 내고 있다.

\section{2. 공시 미생물}

\section{1) 병원성 미생물}

공시한 병원성 미생물은 오염도 측정을 위한 Escherichia coli O157(ATCC 700927D)과 부패도 를 측정하는 Salmonella paratyphi(ATCC 9150), Listeria monocytogenes(KCTC 3569)과 Staphylococcus aureus(KCTC 1621) 등 병원성 미생물 4종을 축

Table 1. Biological active materials used in the experiment

\begin{tabular}{llll}
\hline Materials & Orgrins & Features & Biological activity \\
\hline \hline Garlic extracts & Garlic & liquid & A-M, P-I \\
Scallion extracts & Leeks extrat & liquid & A-M, A-B, P-I \\
Flavonoids & Lacquer tree & powder & A-O, A-B, P-I \\
Urushiol & Lacquer tree & liquid & A-O, A-B, P-I \\
Anthocyanidin & Red grape & powder & A-O, A-B, P-I \\
Bio-MOS $^{\circledR}$ & Microbial cell & powder & A-M, A-B, P-G \\
\hline
\end{tabular}

1) A-O, anti-oxidant; A-M, anti-microbes; A-B, antibiotics; P-I, promotion of immune; P-G, promotion of growth. 
Table 2. Pathogenic microbes and media

\begin{tabular}{lclc}
\hline Pathogenics & Gram & Media & Motility \\
\hline \hline Escherichia coli O157 & - & MacConkey Medium & + \\
Salmonella paratyphi & - & Salmonella-Shigella Medium & + \\
Listeria monocytogenes & + & Listeria Medium & + \\
Staphylococcus aureus & + & Nutrient Medium & - \\
\hline
\end{tabular}

산연구소 동물병원에서 분양 받았다. 병원성 미 생물의 사용배지와 특징은 Table 2에 나타내었 다.

\section{2) 반추위 혼합 미생물}

반추위 cannula가 장착된 한우로부터 분리된 반 추위 혼합 미생물은 Table 3의 Dehority's artificial medium(Dehority, 1965)을 사용하여 Hungate(1966) 의 anaerobic gassing 방법으로 혐기배양 하였다.

\section{3. 조사항목 및 분석방법}

\section{1) 병원성 미생물에 대한 항균활성}

공시 병원성 미생물 4종이 동일량으로 혼합 배양된 시험관에 $0.10 \%$ 의 생리활성물질을 각각 첨가하여 $0,24,48$ 및 96시간 동안 배양한 다 음, 배양액을 채취하여 원심 분리시킨 후 상등 액을 spectrophotometer(Model EZ 201, Perkin Elmer, USA)를 이용하여 $650 \mathrm{~nm}$ 에서 측정하였 다.

항균활성 시험은 paper disc법을 이용하여 각 균주가 배양되어 있는 배지에 멸균증류수를 처 리한 대조구(negative control), 시판 항생제를 처 리한 항생제 처리구(positive control)와 methylene chloride $\left(\mathrm{CH}_{2} \mathrm{Cl}_{2}\right)$ 로 희석한 각각의 생리활성물 질을 농도별 $(0.001,0.01,0.01,1.00,5.00$ 및 $10.00 \%)$ 로 지름 $5 \mathrm{~mm}$ 의 Whatman \#1 filter paper에 $10 \mu \mathrm{l}$ 씩을 흡수시켜 용매는 증발시키고, $37^{\circ} \mathrm{C}$ 에 서 24시간동안 배양 후, clear zone을 관찰하였 다.

\section{2) 반추미생물의 가스 생성량 및 암모니아 농도}

Serum bottle의 Dehority's artificial broth에서
혐기배양 중인 반추위 혼합 미생물에 methylene chloride로 희석한(0.01, 0.10 및 $1.00 \%)$ 각각의 생리활성 물질을 첨가한 후, 처리별 3 반복으로 배양시간대에 따라 가스발생량을 측정하였다.

Table 3. The chemical composition of Dehority's artificial medium

\begin{tabular}{lc}
\hline Ingredients & $100 \mathrm{ml}$ \\
\hline \hline Mineral Solution $\mathrm{I}^{\mathrm{a})}$ & $20 \mathrm{ml}$ \\
Mineral Solution $\square^{\mathrm{b})}$ & $20 \mathrm{ml}$ \\
Reaszurin & $0.1 \mathrm{~g}$ \\
Rumen fluid ${ }^{\mathrm{c})}$ & $40 \mathrm{ml}$ \\
Vitamin Mixture $^{\mathrm{d})}$ & $1.0 \mathrm{ml}$ \\
V.F.A solution $^{\mathrm{e}}$ & $6.7 \mathrm{ml}$ \\
Casein(Acid hydrolyzed casein) & $2 \mathrm{~g}$ \\
Hemin solution & \\
Carbohydrate(C-source) & $0.1 \mathrm{ml}$ \\
8\% $\mathrm{Na}_{2} \mathrm{CO}_{3}$ & $0.5 \mathrm{~g}$ \\
2.5\% Cysteine-HCl & $5 \mathrm{ml}$ \\
\hline
\end{tabular}

a) Mineral solution I : $\mathrm{K}_{2} \mathrm{HPO}_{4} 6.0 \mathrm{~g}$ in $1,000 \mathrm{ml}$ D.W.

b) Mineral solution $\square: \mathrm{CaCl}_{2}$ (anhydrous), $0.25 \mathrm{~g} ; \mathrm{MgSO}_{4}$ (anhydrous), 0.25g; $\mathrm{NaCl}, 4.5 \mathrm{~g}$; (NH4) $\mathrm{SO}_{4}, 4.5 \mathrm{~g}$; $\mathrm{MnSO}_{4} \cdot \mathrm{H}_{2} \mathrm{O}, 0.10 \mathrm{~g} ; \mathrm{FeSO}_{4} \cdot 7 \mathrm{H}_{2}, 0.01 \mathrm{~g}$ in 1,000 ml D.W.

c) Rumen fluid for culture media. Rumen fluid was obtained by filtering rumen contents.

d) Vitamin solution : Pyridoxine $\mathrm{HCl}, 0.20 \mathrm{~g}$; nicotinic acid amide, $0.20 \mathrm{~g}$; Ca-d-pantothenate, $0.20 \mathrm{~g}$; paraamino benzoic acid, $0.01 \mathrm{~g}$; stock soultion $1.0 \mathrm{ml}$ in $1,000 \mathrm{ml}$ D.W.

e) VFA solution : Acetic, $17 \mathrm{ml}(2.9 \times 10-2 \mathrm{M})$; propionic, $6 \mathrm{ml}(8.0 \times 10-3)$, n-valeric, isovaleric, and DL-a -methylbutyric acid, $1 \mathrm{ml}$ each $(9 \times 10-4 \mathrm{M})$.

f) Hemin solution : Dissolove $50 \mathrm{mg}$ hemin in $1 \mathrm{ml}$ $1 \mathrm{~N} \mathrm{NaOH}$; make to $100 \mathrm{ml}$ with water. 
측정 전 - 후의 온도에 의한 오차를 줄이기 위 하여 상온에서 20분간 방치 후, water displacement apparatus를 이용하여 측정하였다(Ferorak 와 Hrwdey, 1983).

배양액의 암모니아의 농도는 Chaney와 Marbach (1962)의 방법에 따라 측정하였다.

3) 반추위 미생물의 carboxymethylcellulase (CMCase) 활성

반추위 혼합 미생물을 배양한 배양액을 1000 $\times \mathrm{g}, 4^{\circ} \mathrm{C}$ 에서 15 분간 원심분리한 후, 상등액을 회수하여 조효소액으로 사용하였다. CMCase 활 성은 Miller(1960)의 방법에 따라 0.1M acetate buffer(pH 5.0)에 CMC $1 \%(\mathrm{w} / \mathrm{v})$ 용액을 기질용 액으로 하여, 위의 조효소액 $0.5 \mathrm{ml}$ 과 $\mathrm{CMC}$ 기 질용액 $0.5 \mathrm{ml}$ 을 혼합하여 $55^{\circ} \mathrm{C}$ 에서 1 시간동안 반응시켜 원심분리한 후, 상층액 $0.2 \mathrm{ml}$ 에 DNS (Dinitrosalicyclic acid) $0.6 \mathrm{ml}$ 을 추가하고, $100^{\circ} \mathrm{C}$ 에서 5 분간 진탕 반응시킨 다음, 상층액내 환 원당 함량을 측정하여 구하였다.

4) 반추위 미생물(박테리아, 프로토조아, 곰 팡이) 수의 측정

반추위 박테리아는 Dehority's artificial medium 에서 혐기배양시킨 후, roll tube방법(Hungate, 1966; Holdman 등, 1977; 이 등, 1995)으로 측정 하였다. 곰팡이는 Lowe's media(Lowe 등, 1985) 에 배양시킨 후, thallus 생성수를 측정하였다. 프로토조아는 살아있는 프로토조아와 죽은 프 로토조아를 구분하여 측정하기 위해 TBFS 용 액(trypan blue-formalin-salin; 증류수 $900 \mathrm{ml}, 35 \%$ formaldehyde 용액 $100 \mathrm{ml}$, trypan blue $2 \mathrm{~g}, \mathrm{NaCl}$ $8 \mathrm{~g}$; dark blue 용액으로 living cell의 핵을 염색) 으로 염색한 후, Abe 등(1972)의 방법에 따라 plankton counter glass를 이용하여 현미경으로 측정하였다.

\section{4. 통계처리}

통계처리는 SAS package program(1996)을 이 용하여 분산분석을 하였고, Duncan의 다중검정 법으로 평균간의 유의성을 검정하였다.

\section{III. 결과 및 고찰}

\section{1. 병원성 미생물의 성장률}

병원성 미생물 배양액에 생리활성 물질을 각 각 $0.10 \%$ 첨가하였을 때, 미생물의 성장률을 조사한 결과는 Fig. 1 에서 보는 바와 같다. 대 조구의 결과로 볼 때, 공시한 병원성 미생물들 (Escherichia coli O157, Salmonella paratyphi, Listeria monocytogenes, Staphylococcus aureus)의 성장은 배양 후 48시간까지 지속적으로 증가하 다가 점차 감소하는 경향을 보였는데, 생리활 성 물질 중 scallion, flavonoid 및 Bio-MOS ${ }^{\circledR}$ 첨 가구에서는 미생물 성장을 억제시켰으나, garlic, urushiol 및 anthocyanidin 첨가구에서는 오히려 더욱 증가되는 것으로 나타났다. 특히, 부추 추 출물인 scallion 첨가구에서는 배양기간 동안 병 원성 미생물이 전혀 자라지 못하는 강력한 항 균력을 가지고 있었다.

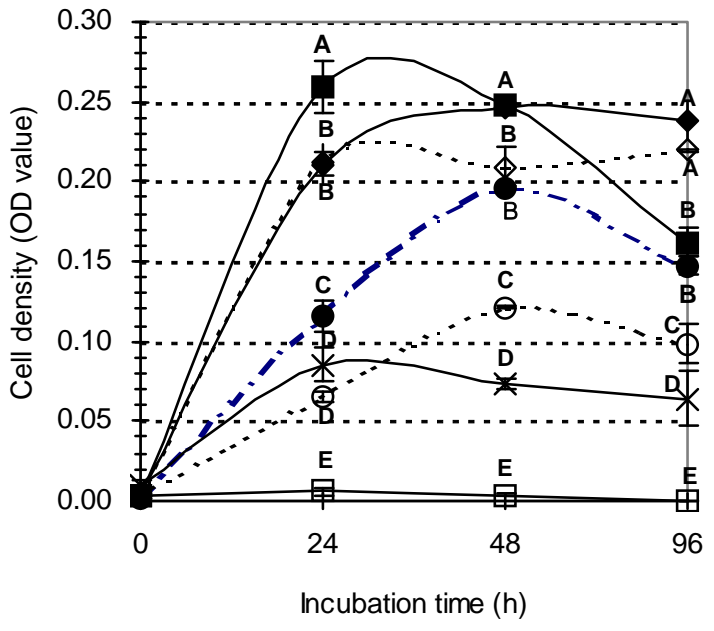

Fig. 1. Effect of $0.10 \%$ biological active materials (- Control; $\diamond \cdots \cdots \cdots \cdots . . . \diamond$, Garlic ; $\square-\square$, Scallion; $x-\times$, Flavonoid ; - U U U U Anthocyanidin; O.......... 0 , Bio-Mos ${ }^{\circledR}$ ) on pathogenic cell growth.

\section{2. 항균활성 시험}

공시 생리활성물질의 병원성 미생물 4종에 대 
한 paper disc법 활성 시험결과는 Fig. 2에서 보 는 바와 같다.

Scallion 및 flavonoid 첨가구에서는 Fig. 1의 미생물 성장률 실험에서와 같이 강한 항균활성 을 나타내었다. 그러나 미생물 성장 실험에서 는 항균효과가 있었던 Bio-MOS ${ }^{\circledR}$ 는 paper disc 법에서는 clear zone을 형성하지 못하였는데, 이 에 대한 이유는 $\mathrm{Bio}^{-\mathrm{MOS}^{\circledR}}{ }^{\circledR}$ 의 경우는 직접적인 항생효과를 나타내는 물질이 아니라 발효산물 과 fimbriae 형성을 통하여 간접적으로 효과를 나타내기 때문으로 사료된다.

특히, 부추 추출물인 scallion의 경우는 $5 \%$ 이 상 농도일 때 모든 병원성 미생물에서 공시한 시판 항생제보다도 더 넓은 clear zone을 형성 함으로써 그람 양성균과 그람 음성균 모두에 활용될 수 있을 만큼 항균 spectrum이 넓고 강
력하여 산업적 활용 가능성이 매우 큰 것으로 나타났다. $5 \%$ 이상 처리 시 항균활성을 나타내 었던 Flavonoid 역시 O157균에는 5\%이상 처리 시 항생제보다 더 넓은 clear zone을 형성하였으 나, Listeria monocytogenes 균과 Staphylococcus aureus에 대해서는 $10 \%$ 처리 시 항균효과가 있 는 것으로 나타났다.

Seo 등(2001)은 백합과 식물(Allium tuberosum) 인 부추에는 살모넬라균, 대장균, 비브리오균 등에 강한 항균력을 나타내는 thiosulfinate 계열 의 휘발성 화합물(S-Methylmethanthiosulfinate; S-Methyl 2-propene-1-thiosulfinate)이 2차 대사산 물로 생성된다고 보고하였다.

수목의 추출성분 중 대표적인 물질군을 이루 고 있는 flavonoid는 현재까지 약 3,000종 이상 의 다양한 구조로 식물계에서 널리 분포하고
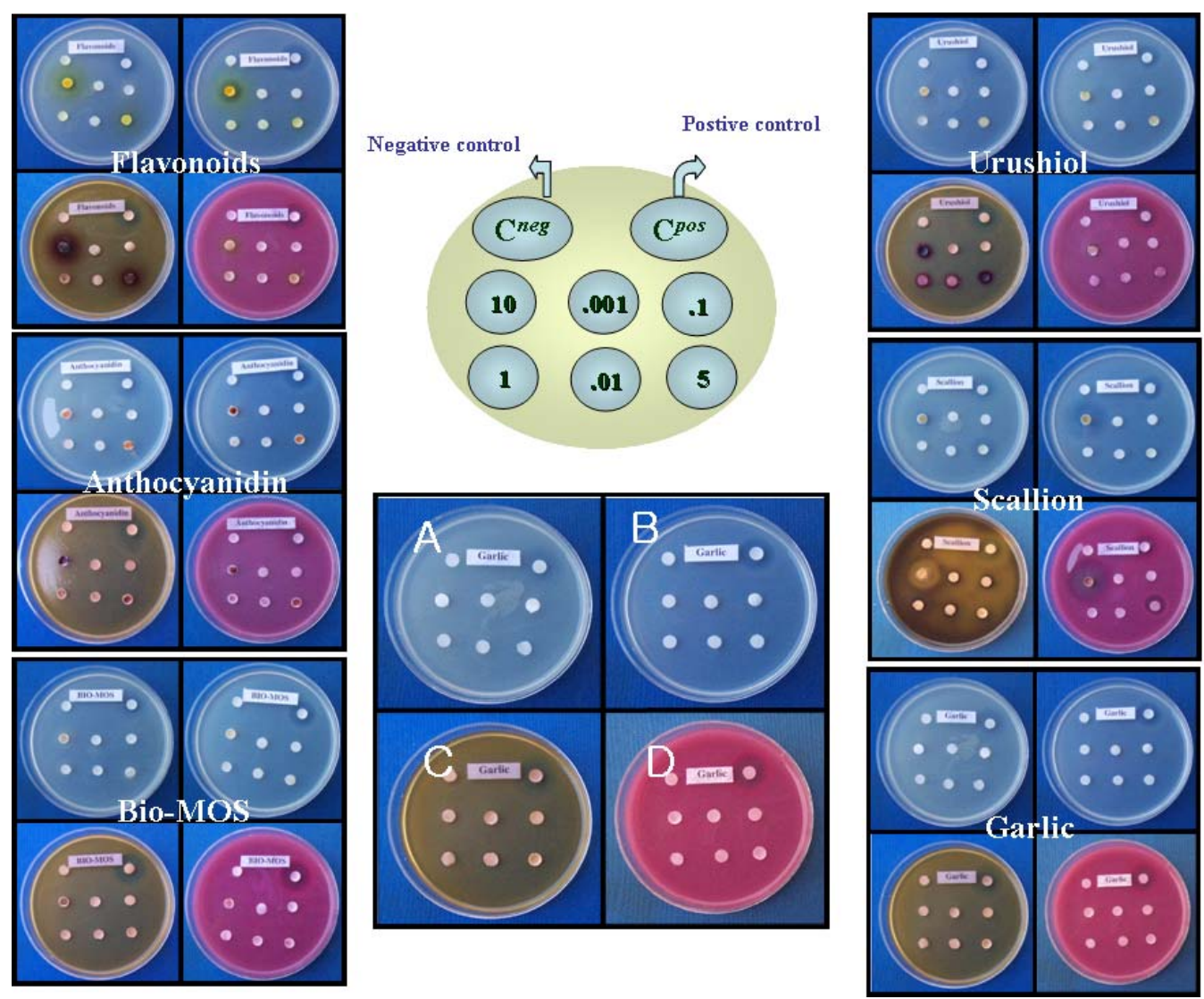

Fig. 2. Clear zone as measured by supplemental levels $(0.001,0.01,0.01,1.00,5.00$ and $10.00 \%$ ) of biological active materials, control and antibiotic treatment. (A, Staphylococcus aureus; B, Listeria monocytogenes; C, Escherichia coli O157; D, Salmonella parathphi). 
있으며 곤충과 균류의 공격에 대한 식물의 방 어기작과 관련이 있는 것으로 알려져 있고 flavanone 구조가 항균활성이 가장 높은 것으로 일반적으로 알려져 있다(Toshimitsu 등, 1988).

부추와 함께 백합과 식물인 마늘에는 allicin 이라는 thiosulfinate 화합물이 주요 항균활성 물 질로서 알려져 있다(Cavallito와 Bailey, 1944). 그러나 마늘 추출물에 존재하는 allicin은 주로 diallyl sulfides로 빠르게 변하기 (Lawson 등, 1991) 때문에 어느 정도 시간이 지나면 항균활 성이 떨어지게 된다(Ross 등, 2001). Lawson 등 (1991)은 HPLC를 이용한 실험에서 실온에서 24시간동안 방치한 마늘 추출물에서 allicin에서 변형된 sulfides가 발견되지 않았다고 하였으며, 공기에 노출되고 수용성이 되어야 하는 agar plate 방법은 휘발성이고 소수성인 마늘유가 항 균력이 나타나지 않은 원인이 될 수도 있다 (Ross 등, 2001)는 보고도 있다. 따라서 본 시험 에서 기존에 항균력이 있다고 알려진 마늘에서 활성이 나타나지 않은 이유도 이러한 제반 원 인들 때문인 것으로 사료된다.

\section{3. 반추위 미생물 발효에 의한 가스 생성량}

In vitro 반추위 미생물 발효(12시간)에 의한 가스 생성량은 Fig. 3에서 보는 바와 같이 garlic
이나 urushiol을 $0.01 \%$ 처리하였을 때 가장 적 었으며, 전 처리구 모두 처리 수준이 증가할수 록 대체로 증가하는 경향이었다. 가스 발생량 과 반추위 미생물 성장이 밀접한 관계가 있음 을 볼 때(Hungate, 1968; Morries등, 1975), 가스 발생량이 많은 처리구가 반추위 미생물 성장률 이 높을 것으로 예측된다.

\section{4. 반추위액 암모니아 농도}

반추위액이 첨가된 in vitro 실험에서 생리활 성물질 6종을 농도별로 처리하여 12시간 배양 후 측정한 암모니아태 질소 농도는 Fig. 4에서 보는 바와 같다. 배양액의 암모니아 농도는 garlic 에서는 $1.00 \%$, scallion에서는 $0.01 \%$ 첨가 시에 만 높고, 타 처리구에서는 거의 비슷한 농도를 나타내었다. 암모니아는 대부분의 반추위 미생 물 성장에 있어 필수적인 질소원이고(Bryant와 Robinson, 1961; Hungate, 1966), 반추위 내에서 생성된 암모니아는 대부분 미생물의 질소원으 로 이용되어 미생물체 단백질로 합성된다. 본 시험에서 암모니아의 농도가 높은 것은 단백질 분해(proteolysis)에 영향을 미친 것으로 사료된 다. 따라서 scallion는 Fig. 4에서 암모니아 농도 가 높은 것으로 보아 단백질 분해에 영향을 미 치는 것으로 사료되어진다. 생리활성물질이 단

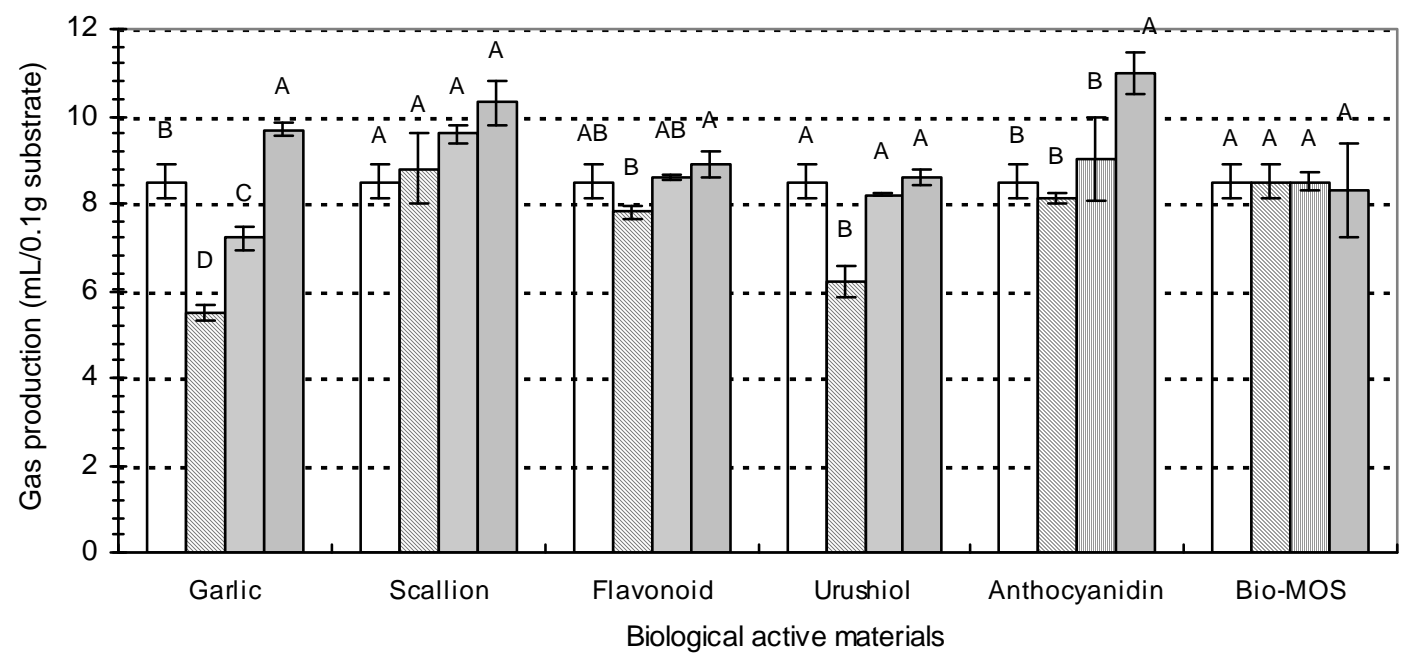

Fig. 3. In vitro gas productions of the supernatant of anaerobic culture medium after $12 \mathrm{~h}$ incubation by supplemental levels of biological active materials. ( $\square$; $0.00 \%, \mathbb{\Delta} ; 0.01 \%$, 血; 0.10\%, 


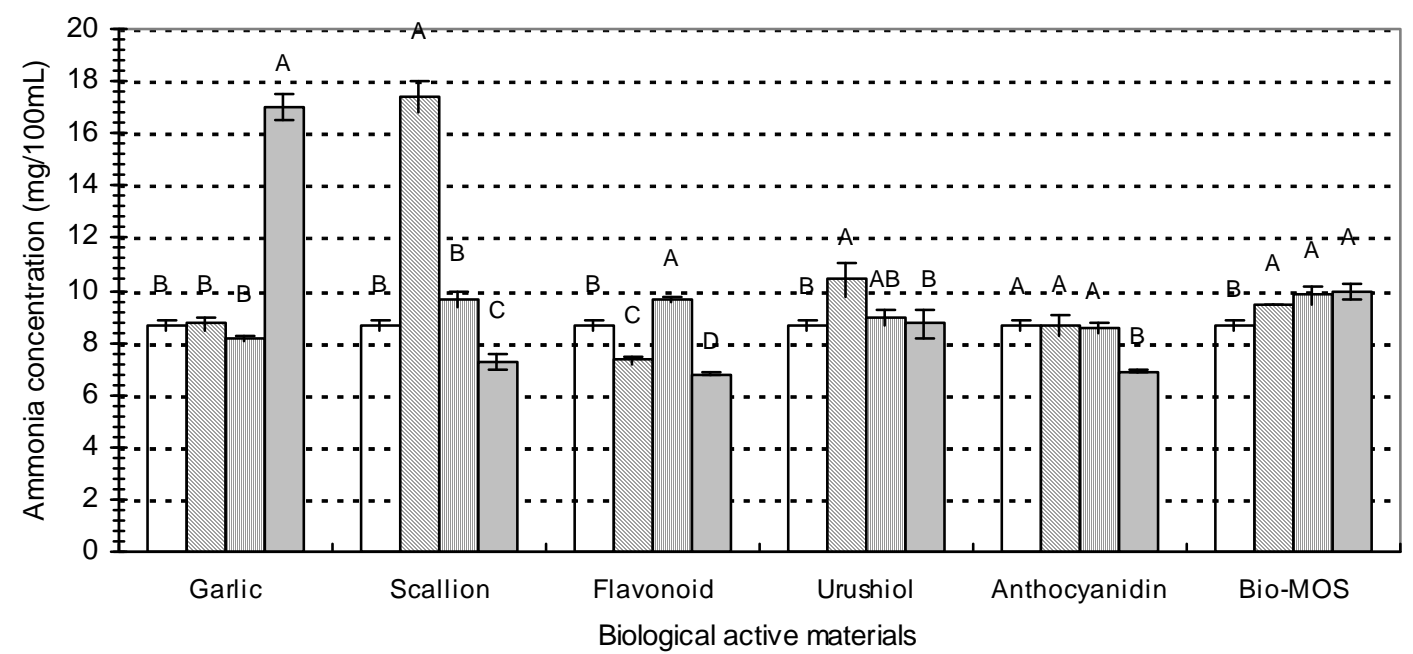

Fig. 4. In vitro $\mathrm{NH}_{4}-\mathrm{N}$ concentrations of the supernatant of anaerobic culture medium after 12 $\mathrm{h}$ incubation by supplemental levels of biological active materials. ( $\square ; 0.00 \%, \mathbb{\nabla} ; 0.01 \%$, 皿; $0.10 \%, \mathbf{\square} ; 1.00 \%)$.

백질 분해 미생물에게 영향을 주는 것으로 사 료되어지나 그 정확한 기전은 알 수 없었다.

병원성 미생물 성장이나 항균활성 시험에서 전혀 활성을 나타내지 못했던 garlic의 경우는 처리 농도 중 가장 고농도인 $1.00 \%$ 처리 시에만 암모니아 농도가 상승하였는데, 이는 본 시험에 서 추출된 garlic에는 병원균에 대한 활성은 없 지만, 반추위 미생물의 단백질 분해 활성을 높 일 수 있는 성분이 있다는 것을 의미하고 있다.

\section{5. 반추위 미생물의 carboxymethylcellulase (CMCase) 활성}

반추위액이 첨가된 in vitro 실험에서 생리활 성물질 6종을 농도별로 처리하여 12시간 배양 후 측정한 반추위 미생물의 CMCase 활성은 Fig. 5에서 보는 바와 같다.

처리 수준 중 가장 높은 농도인 $1.00 \%$ 처리 시, flavonoid와 anthocyanidin 구에서 반추 미생

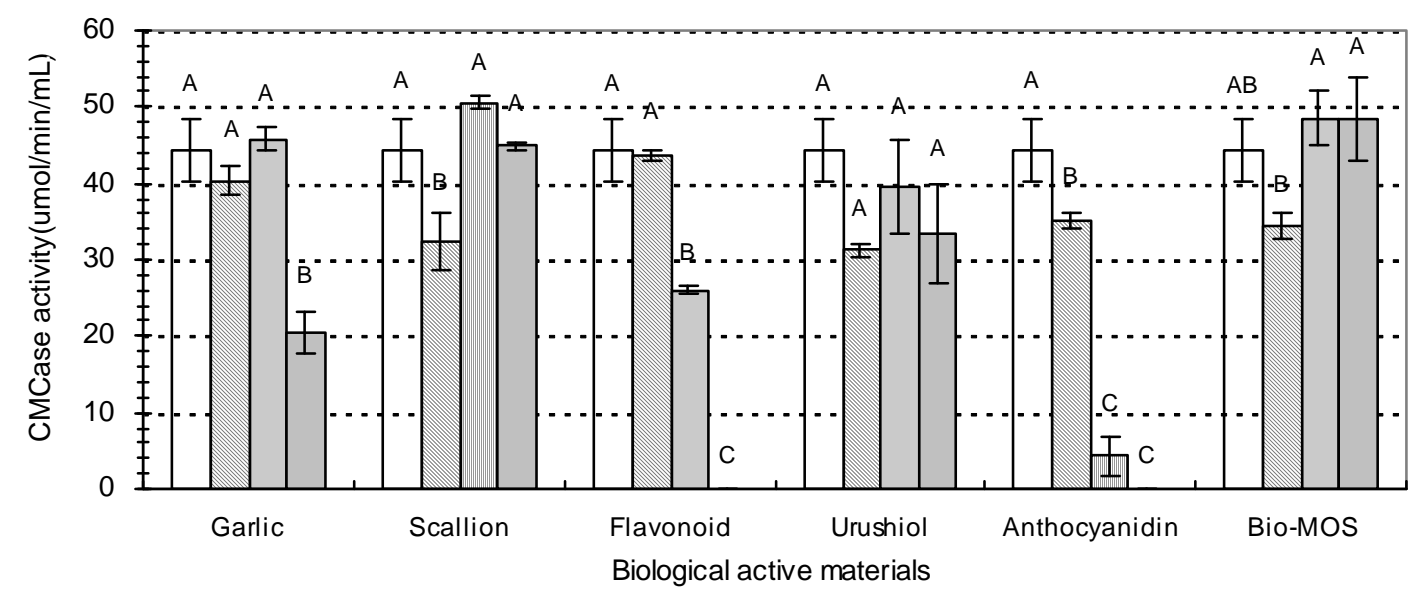

Fig. 5. In vitro CMCase activities of the supernatant of anaerobic culture medium after $12 \mathrm{~h}$

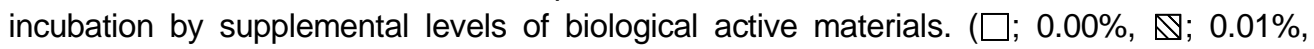
四; 0.10\%, 口; 1.00\%). 
물의 CMCase 활성이 완전히 없어졌으며, garlic 구에서도 무처리 시에 비해 현저히 낮아졌으나 scallion과 Bio-MOS ${ }^{\circledR}$ 구에서는 전혀 차이가 없 었다. 생리활성물질의 처리수준이나 암모니아 생성량과 CMCase의 활성변화의 관계는 일정한 pattern을 나타내지 않았지만, El-Shazly 등(1961) 은 암모니아의 공급은 반추위 미생물에 의한 섬유소 소화를 향상시킨다고 하였는데, 본 시험 에서는 암모니아 생성량이 많았던 $1.00 \%$ garlic 구와 $0.01 \%$ scallion 구에서 CMCase 활성이 무 처리 시에 비해 오히려 낮아졌다.

\section{6. 반추위 미생물 수}

Table 4는 생리활성물질을 $1.00 \%$ 첨가하였을 때, 반추위 미생물(박테리아, 프로토조아, 곰팡 이) 수를 나타내고 있다.

박테리아의 수는 scallion 구와 anthocyanidin 구가 대조구에 비해 많은 편이었고, 프로토조아 의 수는 anthocyanidin 구에서 많고 scallion 구에

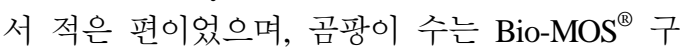
에서 많고 urushiol 구에서 적었으나, 대부분의 생리활성물질이 반추위 박테리아나 곰팡이 군락 에 큰 영향을 미치지는 않았다. 그러나 urushiol 을 반추위액에 첨가하면 반추위 곰팡이가 급격 히 제거되는 것으로 조사되었는데 이러한 이유
는 아직 잘 밝혀져 있지 않으며 앞으로의 연구 에서 urushiol의 어떤 성분이 곰팡이의 성장을 저해시키는지 구명되어져야 할 것으로 생각된 다. Wood 등(1986)은 반추위 곰팡이가 섬유소 분해효소인 cellulase를 분비한다고 하였는데, 본 시험에서 $1.00 \%$ 생리활성물질 첨가구 중, CMCase 활성이 높았던 scallion 구와 Bio-MOS ${ }^{\circledR}$ 구에서 박테리아 수와 곰팡이 수가 각각 가장 많은 것으로 나타나 이들 미생물이 섬유소 분해 와 관계가 있는 것으로 사료된다. 또한, Scallion 은 프로토조아의 성장을 억제하는 경향을 나타 내었는데, 메탄을 생성하는 세균들의 $90 \%$ 가 프 로토조아의 세포벽에 붙어서 생장하는 특징을 가지고 있다(하 등, 2005). 따라서 scallion을 이 용하여 메탄을 생성하는 균들의 서식처인 프로 토조아를 억제하면 메탄 생성량을 저감 시킬 수 있다는 가설을 증명할 추가시험이 요구된 다.

이상의 공시된 생리활성물질들의 병원성 세 균과 반추위 미생물 발효에 미치는 영향을 요 약해 보면, 가스 생성량은 garlic이나 urushiol을 $0.01 \%$ 처리하였을 때 가장 적었으며, 배양액의 암모니아 농도는 garlic에서는 $1.00 \%$, scallion에서 는 $0.01 \%$ 첨가 시에만 높고, 타 처리구에서는 거 의 비슷한 수준이었다. Flavonoid와 anthocyanidin 을 혐기배양액에 $1.00 \%$ 처리하면 반추미생물의

Table 4. Microbial populations after $12 \mathrm{~h}$ incubation of the anaerobic media added $1.00 \%$ of biological active materials

\begin{tabular}{|c|c|c|c|c|}
\hline \multirow{4}{*}{ Ingredients } & \multicolumn{4}{|c|}{ Microbes } \\
\hline & \multirow{2}{*}{ Bacteria } & \multicolumn{2}{|c|}{ Protozoa } & \multirow{2}{*}{ Fungi } \\
\hline & & Live cell & Dead cell & \\
\hline & $\mathrm{cfu}^{1)} \times 10^{8}$ & cell $\times 10^{2}$ & cell $\times 10^{3}$ & $\left(\mathrm{tu}^{2)} \times 10^{4}\right.$ \\
\hline Control & $34.13 \pm 17.02^{b}$ & $41.42 \pm 3.57^{\mathrm{b}}$ & $19.58 \pm 4.37^{\mathrm{b}}$ & $11.27 \pm 6.23^{\mathrm{c}}$ \\
\hline Garlic & $51.24 \pm 11.32^{\mathrm{b}}$ & $63.34 \pm 11.21^{\mathrm{a}}$ & $17.76 \pm 3.62^{\mathrm{b}}$ & $34.16 \pm 8.17^{\mathrm{b}}$ \\
\hline Scallion & $98.14 \pm 23.56^{\mathrm{a}}$ & $11.24 \pm 5.43^{c}$ & $32.45 \pm 10.38^{\mathrm{ab}}$ & $19.27 \pm 6.11^{\mathrm{c}}$ \\
\hline Flavonoid & $43.62 \pm 11.25^{\mathrm{b}}$ & $38.87 \pm 13.57^{\mathrm{ab}}$ & $29.38 \pm 9.22^{\mathrm{ab}}$ & $54.88 \pm 11.01^{\mathrm{a}}$ \\
\hline Urushiol & $47.87 \pm 19.74^{\mathrm{b}}$ & $19.54 \pm 6.54^{c}$ & $48.78 \pm 16.54^{\mathrm{a}}$ & $0.27 \pm 0.19^{\mathrm{d}}$ \\
\hline Anthocyanidin & $89.71 \pm 18.43^{\mathrm{a}}$ & $52.19 \pm 17.35^{\mathrm{ab}}$ & $39.75 \pm 8.73^{\mathrm{ab}}$ & $59.78 \pm 19.17^{\mathrm{ab}}$ \\
\hline Bio-MOS $^{\circledR}$ & $43.77 \pm 13.26^{\mathrm{b}}$ & $57.29 \pm 14.39^{\mathrm{ab}}$ & $22.89 \pm 9.21^{\mathrm{b}}$ & $81.09 \pm 28.47^{\mathrm{a}}$ \\
\hline
\end{tabular}

Mean \pm standard error.

1) colony formation unit/mL, ${ }^{2)}$ thallus formation unit $/ \mathrm{mL}$

Mean with different superscripts in the same microbial fractions differ significantly $(\mathrm{P}<0.05)$. 
CMCase 활성은 완전히 없어졌으며, garlic 구에서 도 무처리 시에 비해 현저히 낮아졌으나 scallion 과 Bio-MOS ${ }^{\circledR}$ 구에서는 차이가 없었다. 대부분 의 생리활성물질이 반추위 박테리아와 곰팡이 군락에 큰 영향을 미치지는 않았다.

병원균에 활성을 나타내었던 flavonoid는 in vitro 반추위 미생물 발효에는 큰 영향을 미치 지는 않았으나 $1.00 \%$ 처리 시 CMCase의 활성 이 완전히 없어짐으로써 반추위 미생물 활성에 억제효과가 있었지만, scallion은 병원균에는 강 한 항균활성을 가지면서 반추위 미생물의 활성 에는 저해작용을 나타내지 않아 반추 가축의 대체 천연항균제로서 개발 가능성이 있는 것으 로 나타났다.

$$
\text { IV. 요 약 }
$$

식물유래 생리활성물질인 garlic, scallion, flavonoid, urushiol 및 anthocyanidin과 기존의 항균 제품인 Bio-MOS ${ }^{\circledR}$ 의 병원성 미생물과 반추위 미생물에 대한 효과를 조사하기 위하여 병원성 균인 Escherichia coli O157, Salmonella paratyphi, Listeria monocytogenes, Staphylococcus aureus에 항균활성과 in vitro 반추위 미생물 성장률, 가 스 생성량, 암모니아 농도, CMCase 활성 및 미 생물 수를 측정하였다.

생리활성물질 $0.10 \%$ 첨가 후, 배양시험에서 는 flavonoid, scallion 및 Bio-MOS ${ }^{\circledR}$ 가 병원성 미 생물의 성장을 억제하였으나, paper disc법에 의 한 항균활성 시험에서는 flavonoid나 scallion을 $5.00 \%$ 이상 처리 시 clear zone이 뚜렷하였으며, scallion이 가장 강력한 항균활성을 가지고 있는 것으로 나타났다.

생리활성물질의 in vitro 반추위 미생물 발효 에 대한 영향은 크지 않았는데, 병원균에 활성을 나타내었던 flavonoid는 $1.00 \%$ 처리 시 CMCase의 활성이 완전히 없어져 반추위 미생물에 대한 억 제효과가 있는 것으로 나타났다. 그러나 scallion 은 병원균에는 강한 항균활성을 가지면서 반추 위 미생물 발효에는 저해작용을 나타내지 않아 반추 가축의 대체 천연항균제로서 개발 가능성 을 나타내었다.

\section{$\mathrm{V} \cdot$ 인 용 문 헌}

1. Abe, M., Shibui, H. and Kumeno, F. 1972. Improved method for counting rumen protozoa. Jap. J. Zootech. Sci. 43:535.

2. Akiko, S., Michiniri, T. and Miyoko, I. 1993. Antibacterial effect of garlic extract on Vibrio parahaemolyticus in fish meat. J. Food Hyg. Soc. Japan 34:63.

3. Ali, M., Thomson, M. and Afzal, M. 2000. Garlic and onions: their effect on eicosanoid metabolism and its clinical relevance. Prostaglnadins. Leulotrienes and Essential Fatty Acids. 62:55.

4. Bryant, M. P. and Robionson, I. M. 1961. An improved nonselective culture medium for ruminal bacteria and its use in determinig diurnal variation in numbers of bacteria in the rumen. J. Dairy Sci. 44:1446.

5. Cavallito, C. J. and Bailey, J. H. 1944. Allicin, the antibacterial principle of Allium sativum. I. Isolation, physical properties, and antibacterial action. J. Am. Chem. Soc. 66:1950.

6. Chaney, A. L. and Marbach, E. P. 1962. Modified reagents for determination of urea and ammonia. Clin. Chem. 8:130.

7. Chen, M. and Wolin, M. J. 1979. Effect of monensin and lasalocid-sodium on the growth of methanogenic and rumen saccharolytic bacteria. Appl. Environ. Microbial. 36:97.

8. Dehority, B. A. 1965. Degradation and utilization of isolated hemi-cellulose by pure cultures of cellulolytic rumen bacteria. J. Bacteriol. 89:1515.

9. El-shazly, K., Dehority, B. A. and Johnson, R. R. 1961. Effect of starch on the digestion of cellulose in vitro and in vivo by rumen micro-organism. J. Anim. Sci. 20:268.

10. Ferorak, P. M. and Hrwdey, S. E. 1983. A simple apparatus for measuring gas production by methanogenic cultures in serum bottles. Environ. Technol. Lett. 4:268.

11. Holdman, L. V., Cato, E. P. and Moore, W. E. C. 1977. Anaerobic laboratory manual(4th ed.), 
Virginia Polutech. Inst. And Sate. Univ. Blackburg, Virginia.

12. Hong, J. H., Lee, M. H., Kang, M. C. and Hur, S. H. 2000. Separation and Identification of Antimicrobial Compounds from Korean Leek. J. Fd hgy. Safety. 15:235

13. Hungate, R. E. 1966. The rumen and it's microbes. Academic press, NY.

14. Hungate, R. E. 1968. Ruminal fermentation. Hand book of physiology. Allimentary canal. Vol. V. pp.2725.

15. Kumar, M. and Berwal, J. S. 1998. Sensitivity of food pathogens to garlic. J. Apple. Microbiol. 84:213.

16. Lawson, L. D. 1991. Identification and HPLC quantitation of the sulphides and $\operatorname{dialk(en)yl}$ thiosulphinates in commercial garlic products. Planta Med. 57:363.

17. Lowe, S. E., Theodorou, M. K., Trinci, A. P. J. and Hespell, R. B. 1985. Growth of an anaerobic rumen fungi on defind and semi-defind media lacking rumen fluid. J. Gen. Microbiol., 131, 2225.

18. Miller, G. L., Blum, R., Glennon, W. E. and Burton, A. L. 1960. Measurement of carboxylmethylcellulase activity. Anal. Biochem. 1:127.

19. Miller, W. C., Theilman, N. M., Swai, N., Cegielski, J. P., Shao, J., Ting, D., Mlalasi, J., Manyenga, D. and Lallinger, G. J. 1996. Delayedtype hypersensitivity testing in Tanzanian adults with HIV infection. J. Acq. Immune Defic. Synd. Human Retrovir. 12:303.

20. Morries, J. G., Baldwin, R. L., Maeng, W. J. and Maeda, B. T. 1975. Basic characteristics of a computer simulated model of nitrogen in the grazing ruminent. Tracer studies on non-protein nitrogen for ruminant. II. International Atomic Energy Agency. Vienna.

21. Mortensen, A., Skibsted, LH., Sampson, J., RiceEvans, C. and Everett, SA. 1997. Comparative mechanisms and rates of free radical scavenging by carotenoid antioxidants. FEBS Lett. 418:91.

22. Ross, Z. M., O'Gara, E. A., Hill, D. J., Sleightolme, H. V. and Maslin, D. J. 2001. Antimicrobial properties of garlic oil against human enteric bacteria: Evaluation of methodologies and comparisons with garlic oil sulfides and garlic powder. Appl. Environ. Microbiol. 67(1):475.

23. Russell, J. B. 1987. A proposed mechanism of monensin action in inhibiting ruminal bacterial growth: Effect on ion flux and proton-motive force. J. Anim. Sci. 64:1519.

24. SAS. 1996 SAS Uaer Guide. Release 6.12 edition. SAS Inst. Inc. Cary NC. USA.

25. Seo, K. I., Moon, Y. H., Choi, S. U. and Park, K. H. 2001. Antibacterial activity of S-methyl methanethiosulfinate and S-methyl 2-propene-1thiosulfinate from chinese chive toward Escherichia coli O157:H7. Biosci. Biotechnol. Biochem., 65(4): 966.

26. Sheo, H. J. 1999. The antibacterial action of garlic, onion, ginger and redpepper juice. J. Korean Soc. Food Sci. Nutr. 28:94.

27. Short, D. E. 1978 . Rumen fermentation and nitrogen metabolism as effected by monensin. Ph. D. Thesis. University of Illinois, Urbana-Champaign.

28. Toshimitsu, H., Kazuko, S., Kawasaki, M., Munehisa, A., Shimizu, M. and Morita, N. 1988. Inhibition of cow's milk xantine oxidase by flavonoids. J. Natural Products. 51:345.

29. Wood, T. M., Wilson, C. A., McCrea, S. I. and Jobin, K. N. 1986. A highly active extracellular cellulase from the anaerobic rumen fungus Neocallimastix frontalis. FEMS. Microbiol. Lett. 43:37.

30. 박윤자, 김미향, 배송자. 2002. 부추 추출 성분의 항발암 효과연구. 한국식품과학회. 34(4):688.

31. 이성실, 하종규, 최윤재, 한인규, 문태현, 김창현. 1995. 반추위 곰팡이의 분리 동정과 섬유소 분해 효소의 특성 규명 및 이들의 산업적 이용에 관 한 연구. II. 볏짚의 화학적 처리와 이의 급여가 축종별 반추위내 곰팡이의 군집변화에 미치는 영향. 한국영양사료학회지. 19:411.

32. 하종규, 이성실, 문양수, 김창현. 2005. 반추동물 영양생리학. 서울대학교출판부. 서울, 대한민국.

(접수일자 : 2006. 8. 16. / 채택일자 : 2006. 10. 24.) 